\title{
Involvement of hippocampal AMPA glutamate receptor changes and the cAMP/protein kinase A/CREB-P signal- ling pathway in memory consolidation of an avoidance task in rats
}

R. Bernabeu1,

M. Cammarota ${ }^{1}$,

I. Izquierdo ${ }^{2}$ and J.H. Medina ${ }^{1}$

\author{
1Instituto de Biología Celular, Facultad de Medicina, Universidad de Buenos Aires, \\ 1121 Buenos Aires, Argentina \\ 2Departamento de Bioquímica, Instituto de Ciências Básicas da Saúde, \\ Universidade Federal do Rio Grande do Sul, 90046-900 Porto Alegre, RS, Brasil
}

\section{Correspondence \\ J.H. Medina \\ Instituto de Biología Celular \\ Facultad de Medicina \\ Universidad de Buenos Aires \\ Paraguay 2155, 3er. piso \\ 1121 Buenos Aires \\ Argentina \\ Fax: 5419625457}

Presented at the XII Annual Meeting of the Federação de Sociedades de Biologia Experimental, Caxambu, MG, Brasil, August 27-30, 1997.

Research supported by PRONEX, Brasil.

Received March 26, 1997 Accepted June 11, 1997

\begin{abstract}
Training in step-down inhibitory avoidance (0.3-mA footshock) is followed by biochemical changes in rat hippocampus that strongly suggest an involvement of quantitative changes in glutamate AMPA receptors, followed by changes in the dopamine $\mathrm{D}_{1}$ receptor/cAMP/ protein kinase A (PKA)/CREB-P signalling pathway in memory consolidation. AMPA binding to its receptor and levels of the AMPA receptor-specific subunit GluR1 increase in the hippocampus within the first $3 \mathrm{~h}$ after training (20-70\%). Binding of the specific $\mathrm{D}_{1}$ receptor ligand, SCH23390, and cAMP levels increase within 3 or $6 \mathrm{~h}$ after training (30-100\%). PKA activity and CREB-P levels show two peaks: a 35-40\% increase $0 \mathrm{~h}$ after training, and a second increase 3$6 \mathrm{~h}$ later $(35-60 \%)$. The results correlate with pharmacological findings showing an early post-training involvement of AMPA receptors, and a late involvement of the $\mathrm{D}_{1} / \mathrm{cAMP} / \mathrm{PKA} / \mathrm{CREB}-\mathrm{P}$ pathway in memory consolidation of this task.
\end{abstract}

From mollusks to mammals, neural plasticity has an early protein synthesis-independent phase that lasts 1-3 $\mathrm{h}$ and directly depends on events related to cell excitation, and a late protein synthesis-dependent phase that lasts hours, days or more and is independent of ongoing electrical activity (1-5). The best studied form of plasticity is longterm potentiation (LTP) in the CA1 subregion of rat hippocampus. In the first 1-3 $\mathrm{h}$, CA1 LTP is accompanied by enhanced $\alpha$ amino-3-hydroxy-5-methyl-isoxazolepropionate (AMPA) receptor sensitivity (2) and
Key words

- Glutamate AMPA receptors

- cAMP/PKA/CREB pathway

- Memory formation

- Rat hippocampus binding properties (3). Persistence of LTP beyond $3 \mathrm{~h}$ requires activation of the cyclic adenylyl monophosphate (cAMP)-responsive element binding (CREB) family of proteins by the cAMP-dependent protein kinase $\mathrm{A}$ (PKA) $(4,5)$. This late phase of LTP is regulated by $\mathrm{D}_{1}$ dopamine receptors, which activate adenylyl cyclase (5). Gene transcription mediated by phosphorylated CREB (CREB$\mathrm{P}$ ) is also crucial for the maintenance beyond $3 \mathrm{~h}$ of serotonin-induced facilitation in Aplysia (6), of memory of odor avoidance in Drosophila (7), and memory of spatial tasks 
in mice (8). We recently showed that activity of hippocampal AMPA receptors within the first $3 \mathrm{~h}(9,10)$, and cAMP/PKA-dependent processes later on (11) are crucial for longterm memory consolidation of a one-trial step-down inhibitory avoidance task in rats.

Here we study levels of the specific AMPA receptor subunit GluR1, AMPA binding to AMPA receptors, $D_{1}$ receptor binding properties, cAMP levels, PKA activity and CREB-P levels in rat hippocampus following inhibitory avoidance training.

Male Wistar rats (3-4 months old, 240$310 \mathrm{~g}$ ) were divided into three groups: animals trained in inhibitory avoidance, naive controls and shocked controls. Trained animals were placed on a 2-cm high, 7 x $25 \mathrm{~cm}$ platform facing a $42 \times 25 \mathrm{~cm}$ grid of $0.1-\mathrm{cm}$ caliber stainless steel bars spaced $1 \mathrm{~cm}$ apart; upon stepping down on the grid they received a $0.3-\mathrm{mA}, 2$-s scrambled footshock (9-11). Shocked controls were placed directly on the grid and exposed to the footshock. Naive controls were just taken out of their home cage. All animals were sacrificed by decapitation.

For binding studies, brains were removed and frozen at $-70^{\circ} \mathrm{C}$. Sagittal $12-\mu \mathrm{m}$ sections were cut with a cryostat, thaw-mounted onto chrome-aluminum gelatin-coated slides and kept at $-70^{\circ} \mathrm{C}$ until incubation. For $\left[{ }^{3} \mathrm{H}\right] \mathrm{AMPA}$ binding, sections were preincubated at $30^{\circ} \mathrm{C}$ in $50 \mathrm{mM}$ Tris- $\mathrm{HCl}$ buffer, $\mathrm{pH} 7.4$, for 30 min, and then incubated at $4^{\circ} \mathrm{C}$ for $4 \mathrm{~h}$ in 100 $\mathrm{mM}$ of the buffer plus $100 \mathrm{mM}$ KCSN and $70 \mathrm{nM}\left[{ }^{3} \mathrm{H}\right]$ AMPA (53 Ci/mmol, NEN, Boston, MA). Nonspecific binding was measured in the presence of $1 \mathrm{mM} \mathrm{L}$-glutamate. For $\left[{ }^{3} \mathrm{H}\right] \mathrm{SCH} 23390$ binding (12), sections were incubated in $50 \mathrm{mM}$ Tris- $\mathrm{HCl}$ buffer, pH 7.4, with $4 \mathrm{nM}\left[{ }^{3} \mathrm{H}\right] \mathrm{SCH} 23390(72.5 \mathrm{Ci} /$ nmol, NEN) at room temperature for $1 \mathrm{~h}$. Incubations were terminated by washing the sections 3 times with the buffer and then in ice-cold water. $\left[{ }^{3} \mathrm{H}\right] \mathrm{SCH} 23390$ and $\left[{ }^{3} \mathrm{H}\right]$ AMPA binding was measured by densitometric analysis of radioautographies as de- scribed elsewhere (10).

GluR1 was measured in synaptic plasma membranes (13) incubated overnight with a polyclonal antibody (Chemicon, Hercules, CA, USA). After addition of $50 \mu \mathrm{l}$ pansorbin, the immune complex was collected by centrifugation, resuspended in $30 \mu \mathrm{l}$ of $1 \times \mathrm{Laem}-$ mli sample buffer, heated first at $50^{\circ} \mathrm{C}$ for 30 min and then at $100^{\circ} \mathrm{C}$ for $2 \mathrm{~min}$, and then subjected to SDS-PAGE and immunoblot (alkaline phosphatase coupled with IgG goat antibody 1/3200, BioRad, Temecula, CA, USA). Densitometry was performed using an MCID image analysis system (5.02 V, Image Research Inc., Toronto, Canada).

For cAMP assays $(9,14)$ the hippocampus was quickly dissected out, placed in 0.5 $M$ sodium acetate buffer with 1-methyl-3butylxanthine for $1 \mathrm{~min}$ at $60^{\circ} \mathrm{C}$, and then homogenized and centrifuged at 12,500 rpm for $10 \mathrm{~min}$. A radioimmunoassay was carried out on the supernatant using $\left[{ }^{125} \mathrm{I}\right] \mathrm{cAMP}$ (25,000-28,000 cpm, NEN) and a specific anti-cAMP antibody (Sigma Chemical Co., St. Louis, MO). cAMP-specific phosphodiesterase activity (PDE) was measured in samples incubated at $37^{\circ} \mathrm{C}$ for $10 \mathrm{~min}$ in 80 $\mathrm{mM}$ Tris buffer $(10 \mathrm{mM} \mathrm{MgCl}, 16 \mathrm{mM} \mathrm{B-}$ mercaptoethanol, $2 \mathrm{mM}$ ATP, $200 \mu \mathrm{M}$ cAMP) plus $70,000 \mathrm{cpm}\left[{ }^{3} \mathrm{H}\right] \mathrm{cAMP}$. Samples were then boiled for $1 \mathrm{~min}$ and incubated with $50 \mu \mathrm{l} 5^{\prime}$-nucleotidase $(1 \mathrm{mg} / \mathrm{ml})$ at $30^{\circ} \mathrm{C}$ for $10 \mathrm{~min}$ and $1 \mathrm{ml}$ of a 1:3 mixture of Dowex X50 resin/methanol was added and centrifuged at 3,000 rpm for $15 \mathrm{~min}$. Supernatants were collected and counted (15).

For PKA activity, hippocampi were homogenized in $20 \mathrm{mM}$ Tris- $\mathrm{HCl}$ buffer, $\mathrm{pH}$ 7.4, with $0.5 \mathrm{mM} \mathrm{IBMX}, 10 \mathrm{mM}$ dithiothreitol, $5 \mathrm{mM} \mathrm{NaF}, 10 \mathrm{mM}$ EDTA, $10 \mathrm{mM}$ EGTA and a mixture of protease inhibitors (16). After centrifugation at $2,800 \mathrm{rpm}$ for $10 \mathrm{~min}$, supernatants were collected and $10-\mu 1$ aliquots $(2 \mathrm{mg}$ protein $/ \mathrm{ml}$ ) were incubated at $30^{\circ} \mathrm{C}$ for $5 \mathrm{~min}$ in buffer containing $30 \mu \mathrm{M}$ kemptide, $10 \mathrm{mM}$ cAMP and $200 \mu \mathrm{M}$ $\left[\gamma^{-32} \mathrm{P}\right]$ ATP $(200-300 \mathrm{cpm} / \mathrm{pmol}, \mathrm{NEN})$. The 
reaction was stopped on phosphocellulose strips which were washed 3 times with 75 $\mathrm{mM}$ phosphoric acid. Filters were dried and counted.

For CREB-P immunocytochemistry (17) rats were anesthetized with chloral hydrate and perfused with $4 \%$ paraformaldehyde in phosphate-buffered saline for $5 \mathrm{~min}$. Brains were removed and exposed for $4 \mathrm{~h}$ at $4^{\circ} \mathrm{C}$ and $20-\mu \mathrm{m}$ sagittal sections were cut with a cryostat and incubated with anti-CREB-P antibody $(0.5 \mu \mathrm{g} / \mathrm{ml})$ for $16 \mathrm{~h}$ at $4^{\circ} \mathrm{C}$. Specific immune complexes were visualized with an avidin biotin detection system (Vector, Brethon, UK) and measured densitometrically as described elsewhere (10).

Data on GluR1 levels, AMPA and SCH23390 binding are shown in Figure 1, and data on cAMP levels, PDE and PKA activity and CREB-P levels are shown in Figure 2.

Maximum $\left[{ }^{3} \mathrm{H}\right]$ AMPA binding increased within the first $2 \mathrm{~h}$ after training in CA1 and this increase was correlated with increased GluR1 levels measured in the same area (Figure 1). The changes suggest translocation of the receptor (18) since they are too rapid to be accounted for by synthesis and are consistent with similar findings on CA1 LTP $(2,3)$, with the retrograde amnestic effect of the infusion of an AMPA antagonist into CA1 being observed within the first $2 \mathrm{~h}$ after training (9). In another study (10) we observed post-training increases of $\left[{ }^{3} \mathrm{H}\right]$ AMPA binding in CA2 and CA3 lasting 24 $\mathrm{h}$; it is possible that those very late changes were related to receptor synthesis $(9,10)$.

8-Br-cAMP and the adenylyl cyclase activators, forskolin and SKF38393 (a selective dopamine $\mathrm{D}_{1}$ receptor agonist), infused 3 or $6 \mathrm{~h}$ post-training into the rat hippocampus, enhance retention of the avoidance task, whereas the PKA inhibitor, KT5720, or the $\mathrm{D}_{1}$ antagonist, $\mathrm{SCH} 23390$, is amnestic (11). In the present report we show that, indeed, there was enhanced binding of labeled SCH23390 to the receptor in the hippocam-

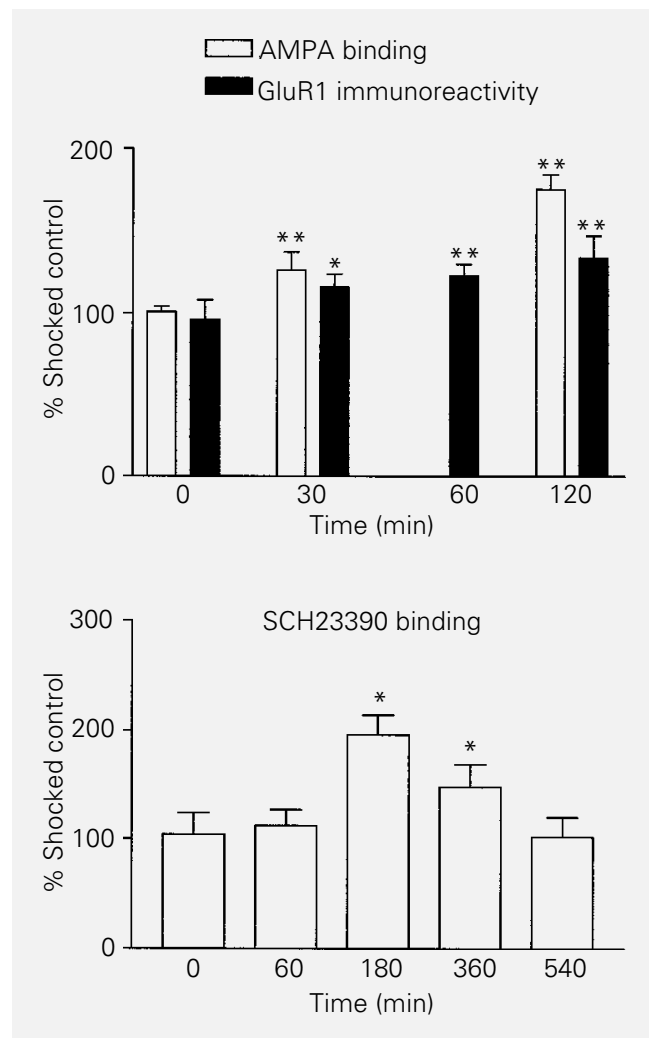

Figure 1 - In this and in the following figure, data are from animals sacrificed at various times after step-down inhibitory avoidance training (abscissae, in min) and are reported as \% values of shocked controls (ordinates). Top panel, GluR1 levels measured by immunoblot and $\left[{ }^{3} \mathrm{H}\right]$ AMPA binding to AMPA receptors in the CA1 area of the hippocampus at different times after training. ${ }^{*} \mathrm{P}<0.05$, ${ }^{*} \mathrm{P}<0.01$ compared to shocked controls (Newman-Keuls after ANOVA). Bottom panel, Mean \pm SEM densitometric values of $\left[{ }^{3} \mathrm{H}\right]$ $\mathrm{SCH} 23390$ binding to the hippocampal pyramidal cell layer at different times after training. There was maximum binding at 180 min, a slight decrease at 360 min, and a return to control values at $540 \mathrm{~min}$. ${ }^{*} \mathrm{P}<0.01 \mathrm{com}$ pared to shocked controls (Newman-Keuls after ANOVA). Number of independent experiments ranged between 5-8 per group.

pus 3 or 6 , but not 0,1 or $9 \mathrm{~h}$ after training (Figure 1).

cAMP levels increased 3 or 6 but not 0 or $9 \mathrm{~h}$ post-training and this increase was not accompanied by detectable changes in PDE, and therefore may be attributed to activation of adenylyl cyclase. Two peaks of PKA activity and CREB-P levels were observed: one $0 \mathrm{~h}$ after training, and a second, higher one at 3 and $6 \mathrm{~h}$ after training (Figure 2). All effects were learning-specific: in all cases, differences between naive and shocked controls were nonsignificant (data not shown; see also 9,10).

The data suggest that an increase of AMPA receptor function, followed by activation of the $\mathrm{D}_{1} / \mathrm{cAMP} / \mathrm{PKA} / \mathrm{CREB}-\mathrm{P}$ pathway, is crucially involved in memory consolidation of inhibitory avoidance learning in the rat. Previous studies on full retrograde amnesia by intrahippocampal infusion of an AMPA antagonist within the first $3 \mathrm{~h}$ after training (9) or of PKA inhibitors or $\mathrm{SCH} 23390$ (11) within the following $3 \mathrm{~h}$ 

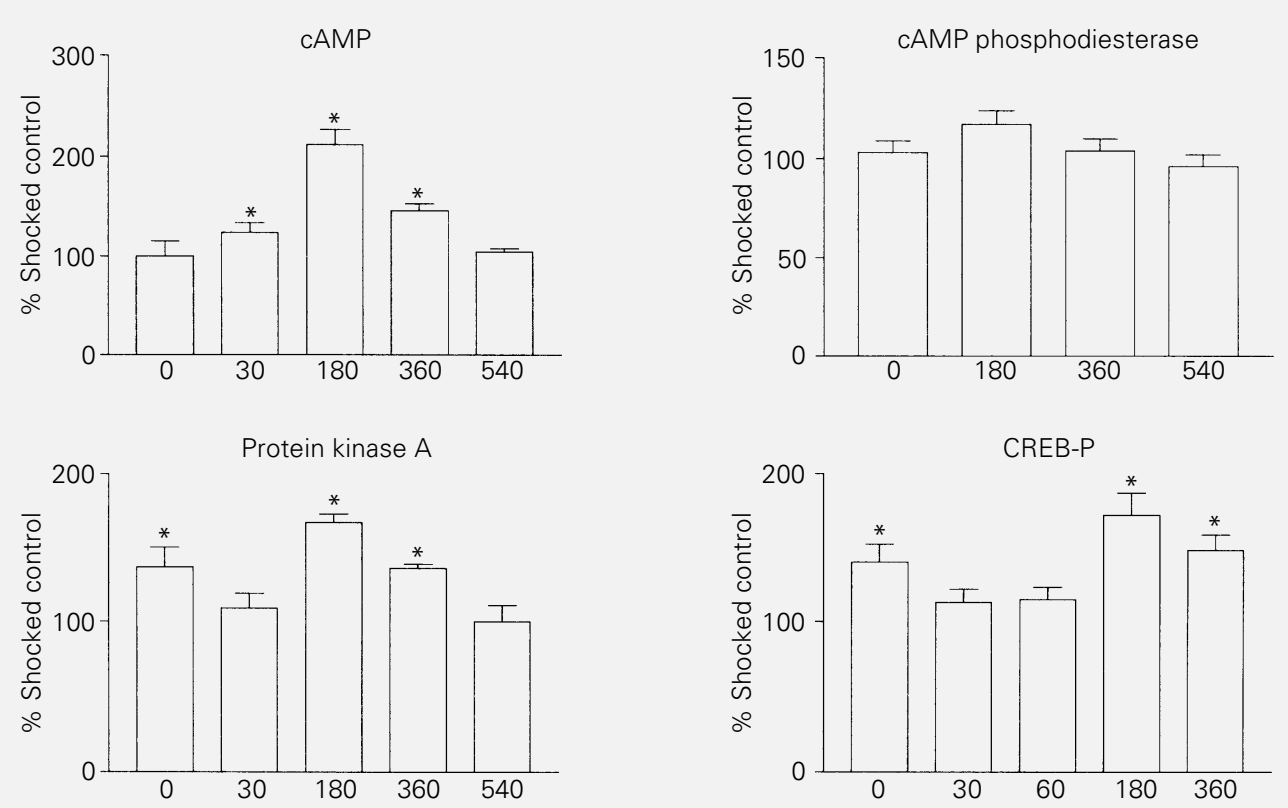

Figure 2 - Top left panel, Mean \pm SEM cAMP levels in extracts of rat hippocampus measured with a specific antibody (Sigma). There was a peak at $180 \mathrm{~min}$, a slight decrease at $360 \mathrm{~min}$, and a return to control values at 540 min. ${ }^{*} \mathrm{P}<0.02$ by Newman-Keuls after ANOVA; $N=5$ independent experiments done in duplicate. Top right panel, Mean \pm SEM cAMP phosphodiesterase activity (PDE) measured by the hydrolysis of $\left[{ }^{3} \mathrm{H}\right] \mathrm{CAMP}$. No changes were detected at any time after training; $N=6$ independent experiments done in duplicate. Bottom left panel, Mean \pm SEM levels of PKA activity measured by the phosphorylation of kemptide. There was a peak immediately after training, followed by a return to control values, and a second, higher peak at 180 and $360 \mathrm{~min}$. ${ }^{*} \mathrm{P}<0.01$ by Newman-Keuls after ANOVA; $N=5$ independent experiments done in triplicate. Bottom right panel, Mean \pm SEM of CREB-P immunoreactivity obtained by densitometric analysis of specific immune complexes of CREB-P with a specific antibody (provided by Prof. D.D. Ginty) visualized in histological sections with an avidin biotin detection system. As with PKA, there were two peaks of CREB-P: the first 0 min after training, and the second at 180 min. ${ }^{*} \mathrm{P}<0.01$ by Newman-Keuls after ANOVA; $N=5$ independent experiments done in duplicate.

indicate that both processes are essential for memory formation.

The first, early peak of PKA and CREB$P$ precedes the onset of the cAMP increase and dopaminergic regulation and may be related to the production of early post-training protein messengers recently suggested for spatial learning in the rat hippocampus (19). The second PKA/CREB-P peak at 3-6 $\mathrm{h}$ was accompanied by high cAMP levels and enhanced $\left[{ }^{3} \mathrm{H}\right] \mathrm{SCH} 23390$ binding, and may correlate with enhanced glycoprotein synthesis and synaptic structural changes as described in rat hippocampus 5-7 h after training (20).

\section{Acknowledgments}

We are grateful to Drs. D.D. Ginty (Harvard Medical School) and D. Golombek (Universidad de Buenos Aires) for their gift of the anti-CREB-P antibody. 


\section{References}

1. Carew TJ (1996). Molecular enhancement of memory formation. Neuron, 16: 5-8.

2. Sergueeva OA, Fedorov NB \& Reymann KG (1993). An antagonist of glutamate metabotropic receptors, (R)-methyl-4carboxyphenyl glycine, prevents the LTPrelated increase in postsynaptic AMPA sensitivity in hippocampal slices. Neuropharmacology, 32: 933-935.

3. Tocco G, Maren G, Shors TJ, Baudry M \& Thompson RF (1992). Long-term potentiation is associated with increased $\left[{ }^{3} \mathrm{H}\right] \mathrm{AMPA}$ binding in rat hippocampus. Brain Research, 573: 228-234.

4. Huang $Y Y$, Li XC \& Kandel ER (1994). CAMP contributes to mossy fiber LTP by initiating both a covalently mediated early phase and a macromolecular-synthesis dependent late phase. Cell, 79: 69-79.

5. Huang $Y-Y$ \& Kandel ER (1995). $D_{1} / D_{5}$ receptor agonists induce a protein-synthesis-dependent late potentiation in the CA1 region of the hippocampus. Proceedings of the National Academy of Sciences, USA, 92: 2446-2450.

6. Bartsch D, Ghirardi M, Skehel PA, Karl KA, Herder SP, Chen M, Bailey CH \& Kandel ER (1995). Aplysia CREB2 represses longterm facilitation: Relief of expression converts transient facilitation into long-term functional and structural changes. Cell, 83: 979-992.

7. Yin JCP \& Tully T (1996). CREB and the formation of long-term memory. Current Opinion in Neurobiology, 6: 426-428.
8. Bourchuladze R, Frenguelli B, Blendy J, Cioffi FD, Schutz G \& Silva AJ (1994). Deficient long-term memory in mice with a targeted mutation of the CAMP-responsive element-binding protein. Cell, 79: 5968.

9. Izquierdo I \& Medina JH (1997). The biochemistry of memory and its regulation by hormones and neuromodulators. Psychobiology (in press).

10. Cammarota M, Bernabeu R, Izquierdo I \& Medina JH (1996). Reversible changes in hippocampal [3H]-AMPA binding following inhibitory avoidance training in the rat. Neurobiology of Learning and Memory, 66: 85-88.

11. Bevilaqua L, Ardenghi $P$, Schröder N, Bromberg E, Quevedo J, Schmitz PK, Bianchin M, Walz R, Schaeffer E, Medina JH \& Izquierdo I (1997). Agents that affect cAMP levels or protein kinase A activity modulate memory consolidation when injected into rat hippocampus but not amygdala. Brazilian Journal of Medical and Biological Research, 30: 967-970.

12. Stewart MG, Kabai $P$, Harrison E, Steele RJ, Kossut M, Gierdalski M \& Csillag A (1996). The involvement of dopamine in the striatum in passive avoidance training in the chick. Neuroscience, 70: 7-14.

13. De Robertis E, Pellegrino de Iraldi A, Rodríguez de Lores Arnaiz G \& Gomez CJ (1961). On the isolation of nerve endings and synaptic vesicles. Journal of Biophysical and Biochemical Cytology, 9: 229-235.
14. Domino S, Tubb DJ \& Garbers DL (1991) Assay of guanylyl cyclase catalytic activity. Methods in Enzymology, 195: 345355.

15. Thompson W, Broker $G$ \& Appleman $M$ (1974). Assay of phosphodiesterases. Methods in Enzymology, 38: 205-212.

16. Clegg $\mathrm{CH}$, Correll LA, Cadd GG \& McKnight GS (1987). Inhibition of intracellular cAMP-dependent protein kinase using mutant genes of the regulatory type I subunit. Journal of Biological Chemistry, 262: 13111-13119.

17. Ginty DD, Kornhauser JM, Thompson MA, Bading H, Mayo KE, Takahashi JS \& Greenberg ME (1993). Regulation of CREB phosphorylation in the suprachiasmatic nucleus by light and a circadian clock. Science, 260: 238-241.

18. Baudry M, BiX \& Tocco G (1996). The role of glutamate receptor regulation in memory processes. In: McGaugh JL, Ishikawa K \& Sakata S (Editors), Brain Processes and Memory. Elsevier/North Holland, Amsterdam, 97-115.

19. Frey U \& Morris RGM (1997). Synaptic tagging and long-term potentiation. Nature, 385: 533-536.

20. O'Connell C, O'Malley A \& Regan CM (1997). Transient learning-induced ultrastructural change in spatially-clustered dentate granule cells of the adult rat hippocampus. Neuroscience, 76: 55-62. 